\title{
The importance of habitat mosaics for Orthoptera (Caelifera and Ensifera) in dry heathlands
}

\author{
JENS SCHIRMEL ${ }^{1}$, IRMGARD BLINDOW ${ }^{1}$ and THOMAS FARTMANN ${ }^{2}$ \\ ${ }^{1}$ Biological Station of Hiddensee, University of Greifswald, Biologenweg 15, 18565 Hiddensee/Kloster, Germany; \\ e-mails: jens_schirmel@web.de, blindi@uni-greifswald.de \\ ${ }^{2}$ Department of Community Ecology, Institute of Landscape Ecology, University of Münster, Robert-Koch-Straße 26, \\ 48149 Münster, Germany; e-mail: fartmann@uni-muenster.de
}

Key words. Orthoptera, Caelifera, Ensifera, Calluna heath, coastal heath, grey dune, heathland

\begin{abstract}
In summer 2008, the Orthopteran species Chorthippus biguttulus, Myrmeleotettix maculatus (Caelifera), Decticus verrucivorus and Platycleis albopunctata (Ensifera) were sampled in coastal heathland on the German Baltic Sea island of Hiddensee. The aim of this study was to assess differences in abundance of Orthoptera in three different habitats and determine the importance of habitat mosaics. Distribution patterns varied among species and total abundance of Orthoptera differed significantly among the three habitats. Due to species-specific habitat preferences the Caelifera were most abundant in grey dunes and the Ensifera in dwarf-shrub heath adjoining grey dunes. In conclusion, grey dunes are a suitable habitat for the Caelifera studied, while the Ensifera require a heathland mosaic consisting of both grey dunes and dwarf shrub vegetation.
\end{abstract}

\section{INTRODUCTION}

Heath ecosystems are protected under the EU Habitats Directive (Ssymank et al., 1998). Like many other dry, nutrient-poor open habitats (e.g. calcareous and sandy dry grassland, inland and coastal dunes) they harbour a high biodiversity, especially of insects (Webb, 1998; van Swaay, 2002; Riksen et al., 2006). Typical heath ecosystems are characterized by a mosaic of dwarf-shrub vegetation, grass-dominated heath, bare ground and isolated shrubs or trees. According to the habitat heterogeneity hypothesis (Tscharntke et al., 2002; Tews et al., 2004) there should be a greater diversity of insects in complex than simple habitats, as the number of niches increases with increase in habitat complexity (Dupont \& Overgaard Nielsen, 2006).

The dune heath on the Baltic Sea island of Hiddensee is dominated by Calluna vulgaris heath, except on the grey dunes, which are dominated by Corynephorus canescens. Typical Orthoptera present in the Hiddensee dune heath are the Caelifera Chorthippus biguttulus (Linnaeus, 1758) and Myrmeleotettix maculatus (Thunberg, 1815) (Köhler \& Reinhardt, 2002) and Ensifera Decticus verrucivorus (Linnaeus, 1758) (Köhler \& Reinhardt, 2002) and Platycleis albopunctata (Goeze, 1778) (Schirmel et al., 2010).

The aim of this study was to answer the following questions: (i) How do the abundances of the different species of Orthoptera differ among the three habitats a) grey dune, b) adjoining heath and c) heath located at least $20 \mathrm{~m}$ away from the grey dunes? (ii) How can the abundance patterns of the species be explained? (iii) What can be concluded from this study about the conservation of heathland Orthoptera?

\section{MATERIAL AND METHODS}

The study area was the dune heath on the Baltic Sea island of Hiddensee, Germany $\left(54^{\circ} 32^{\prime} \mathrm{N}, 13^{\circ} 5^{\prime} \mathrm{E}\right.$; Fig. 1a). It is a distinctive feature of the landscape and covers an area of about 200 ha. The average annual precipitation is $547 \mathrm{~mm}$ and average annual temperature $7.5^{\circ} \mathrm{C}$ (Reinhard, 1962). After cultivation of the land was abandoned about 100 years ago, the landscape was kept open by clearing shrubs, sod cutting, mowing and, since 2004, sheep grazing. Plant cover consists mainly of Calluna vulgaris and small-scale occurrence of grey dune vegetation (Corynephorus canescens, Carex arenaria and Cladonia spp.).

Three habitats were sampled a) grey dunes (GD), b) dwarfshrub heath adjoining grey dunes (HN) and c) dwarf-shrub heath at least $20 \mathrm{~m}$ away from grey dunes (HF). Five $500 \mathrm{~m}^{2}$ sites at which the vegetation was homogeneous were established in each habitat. The sites in the GD were at least $5 \mathrm{~m}$ from dwarfshrub heath. At least one side of the rectangular HN sites was situated at a maximum of $5 \mathrm{~m}$ from grey dunes and the HF sites were at least $20 \mathrm{~m}$ from grey dunes (Fig. 1b).

The structure of the vegetation in each of the three habitats was characterized at the beginning of August by recording the following parameters: total vegetation cover, grass cover (including sedges), cryptogam cover (all estimated in \%) and vegetation height $(\mathrm{cm})$. At each site, the vegetation was sampled in three $2 \times 2 \mathrm{~m}(\mathrm{GD})$ or two $5 \times 5 \mathrm{~m}(\mathrm{HN}, \mathrm{HF})$ randomly located squares, respectively.

The Orthoptera were recorded by slowly walking along transects three times between the end of July and end of August 2008. At each site transects consisted of loops of a total length of $70 \mathrm{~m}$. All visually and acoustically detected individuals at a distance of up to $0.5 \mathrm{~m}$ on both sides of transects (total area sampled per site $=70 \mathrm{~m}^{2}$ ) were counted. Scientific nomenclature followed Coray \& Lehmann (1998).

One-way ANOVA followed by Fisher's LSD post-hoc tests were used for the results that met ANOVA assumptions. If necessary, a $\log (x+1)$ transformation was used, and for results that still deviated from normality, the Kruskal-Wallis test followed by multiple U-test comparisons (Bonferroni-corrected to a significance level of $\alpha \leq 0.017$ ) were performed. For all tests, the SPSS 11.5 statistics package was used.

\section{RESULTS}

Except for the cover of cryptogams (GD: $61.0 \pm 3.0 ; \mathrm{HN}$ : $66.2 \pm 1.6$; HF: $66.4 \pm 2.1$ ), all the other vegetation parameters recorded for the grey dunes differed highly significantly from 


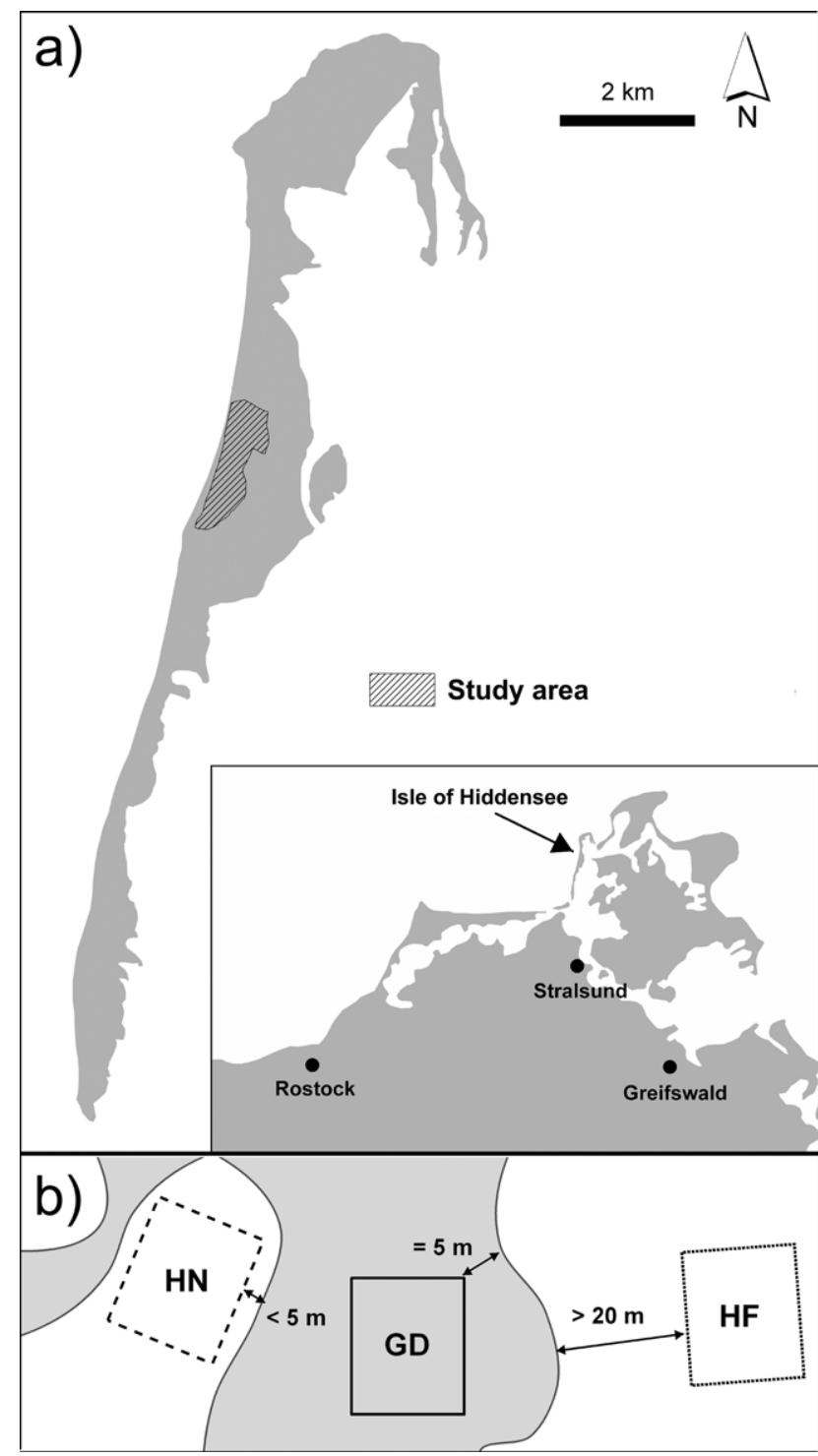

Fig. 1. The a) position of the isle of Hiddensee at the Baltic Sea (small map) and of the study area (hatched) and the b) placement of the sampling sites in the study area. GD = grey dunes, distance of at least $5 \mathrm{~m}$ from the dwarf-shrub stands $(\mathrm{n}=5), \mathrm{HN}=$ dwarf-shrub heath adjoining to grey dunes $(\mathrm{n}=5), \mathrm{HF}=$ dwarf-shrub heath $>20 \mathrm{~m}$ away from grey dunes $(\mathrm{n}=5)$; white $=$ homogeneous dwarf-shrub stands (Calluna vulgaris), grey = grey dunes (Corynephorus canescens).

those for the dwarf-shrub heath. The grey dunes had lower cover of total vegetation $(59.0 \pm 1.3)$, higher cover of grasses $(39.4 \pm 2.2)$ and a shorter turf $(25.8 \pm 1.0)$, compared to $\mathrm{HN}$ $(88.4 \pm 2.3 ; 3.4 \pm 1.3 ; 54.0 \pm 2.5)$ and $\mathrm{HF}(89.4 \pm 2.0 ; 4.0 \pm 1.2$; $60.6 \pm 1.2)$, respectively. The only vegetation parameter that differed significantly between the two types of heath was the height of the vegetation, which was slightly higher on the HF $(60.6 \pm 1.2)$ than $\mathrm{HN}(54.0 \pm 2.5)$.

All four species of Orthoptera were recorded in the GD and HN (Table 1). In HF only C. biguttulus, M. maculatus, and $D$. verrucivorus were observed. Total numbers of individuals recorded decreased from GD (537 individuals) to HN (208 individuals) to HF (94 individuals). Mean abundances per $10 \mathrm{~m}^{2}$ of the four species decreased from GD $>\mathrm{HN}>\mathrm{HF}$ and differed significantly among habitat types. C. biguttulus abundances decreased significantly from GD $>\mathrm{HN}>\mathrm{HF}$. Abundance of
M. maculatus also decreased from GD $>\mathrm{HN}>\mathrm{HF}$. However, the abundances in the two dwarf-shrub heaths did not differ significantly. D. verrucivorus was most abundant in $\mathrm{HN}$ and differed significantly from that in GD but not HF. P. albopunctata was absent in $\mathrm{HF}$ and did not differ in abundance in GD and HN (Table 1).

\section{DISCUSSION}

As the Orthoptera differ in their life-history traits (Ingrisch \& Köhler, 1998; Braschler et al., 2009) it was expected that they would differ in their distribution among the habitats studied. The Caelifera $C$. biguttulus and $M$. maculatus were most abundant in grey dunes. Both species are heat-loving and require open and warm oviposition sites (Detzel, 1998) and M. maculatus, especially, prefers habitats with little vegetation (Detzel, 1998; Willot \& Hassall, 1998). Both species were also recorded in dwarf-shrub heath (HN, HF), but only in small numbers. M. maculatus requires very little space and can survive in extremely small microhabitats (Detzel, 1998), which might account for its presence in heath vegetation. Moreover, M. maculatus is only partly graminivorous (Zehm, 1997) and therefore capable of finding sufficient food (such as mosses) in the nearly grass-free dwarf-shrub heath. This might be why its abundance in $\mathrm{HN}$ and $\mathrm{HF}$ did not differ significantly. In contrast, the spatial proximity to grey dunes positively influenced the abundance of $C$. biguttulus in dwarf-shrub heath (more abundant in $\mathrm{HN}$ than HF). This could be due to the high proportion of grasses, the preferred food of this orthopteran, in grey dunes.

As in most large-sized grassland Ensifera (Gottschalk, 1997; Schuhmacher \& Fartmann, 2003; Braschler et al., 2009) the occurrence of the Ensifera D. verrucivorus and P. albopunctata strongly depends on the existence of habitat mosaics, as in the different stages of their life cycle they require different environmental conditions. Like the two Caelifera species, $D$. verrucivorus and $P$. albopunctata need bare ground for oviposition (Ingrisch \& Boekholt, 1983; Gottschalk, 1997) and their heat-loving nymphs (Ingrisch, 1978) depend on sparsely vegetated microhabitats (Schuhmacher \& Fartmann 2003). On the other hand, the adults of the two Ensifera species are bigger (18-44 mm; Detzel, 1998) than the Caelifera (11-23 mm; Detzel, 1998) and therefore require taller (dwarf-shrub) vegetation for shelter and song posts (Schuhmacher \& Fartmann, 2003; Braschler et al., 2009). These requirements account for the high abundance of $D$. verrucivorus and $P$. albopunctata in heath adjoining grey dunes. The high abundance of $P$. albopunctata in GD may also be due to its higher heat requirement and the presence there of grasses, as it prefers to feed on grass seeds (Gottschalk, 1997).

Our results indicate that extensive, homogeneous and undisturbed stands of dwarf-shrub heath are not optimum habitats for many Orthoptera (Clausnitzer, 1994; Stuke, 1995). Only $M$. maculatus and D. verrucivorus tend to occur regularly in large numbers in such habitats. In contrast, grey dunes or disturbed areas are very suitable habitats for the Caelifera studied and in combination with neighbouring heath are also suitable for some Ensifera (Schuhmacher \& Fartmann, 2003). Therefore, the conservation of species- and individual-rich heathland Orthopteran communities depends on the creation of heterogeneous heathland with open dunes and disturbed patches next to Calluna stands.

The Orthopteran fauna of homogeneous Calluna heaths can be considerably influenced by the nature of the adjacent habitats, as shown for grey dunes in this study. To avoid edge effects, the minimum distance of a plot from adjacent habitats should be at least $20 \mathrm{~m}$, when recording the indigenous Orthop- 
TABLE 1. The abundance of Orthoptera (mean number of individuals per $10 \mathrm{~m}^{2} \pm \mathrm{SE}$ ) in grey dunes $(\mathrm{GD}, \mathrm{n}=5)$, dwarf-shrub heath adjoining grey dunes $(\mathrm{HN}, \mathrm{n}=5)$ and dwarf-shrub heath at least $20 \mathrm{~m}$ away from grey dunes $(\mathrm{HF}, \mathrm{n}=5)$, and the results of one-way ANOVA's or Kruskal-Wallis tests. Different letters indicate significant differences between abundances (Fisher's LSDTest at $P \leq 0.05$; Kruskal-Wallis test: Bonferroni-corrected U-Test at $P \leq 0.017$ ).

\begin{tabular}{|c|c|c|c|c|}
\hline & GD & $\mathrm{HN}$ & $\mathrm{HF}$ & Statistics \\
\hline All species & $5.11 \pm 0.45^{\mathrm{a}}$ & $1.98 \pm 0.23^{\mathrm{b}}$ & $0.90 \pm 0.23^{\mathrm{c}}$ & $\begin{array}{l}\mathrm{F}=45.288, \text { d.f. }=2, P \leq 0.001 \\
\text { GD-HN: } P<0.001 \\
\text { GD-HF: } P<0.001 \\
\text { HN-HF: } P=0.037\end{array}$ \\
\hline Chorthippus biguttulus & $1.27 \pm 0.14^{\mathrm{a}}$ & $0.45 \pm 0.12^{b}$ & $0.07 \pm 0.02^{\mathrm{c}}$ & $\begin{array}{l}\chi^{2}=12.750, \text { d.f. }=2, P \leq 0.01 \\
\text { GD-HN: } P \leq 0.01 \\
\text { GD-HF: } P \leq 0.01 \\
\text { HN-HF: } P \leq 0.01\end{array}$ \\
\hline Myrmeleotettix maculatus & $3.68 \pm 0.49^{\mathrm{a}}$ & $1.18 \pm 0.15^{b}$ & $0.71 \pm 0.25^{\mathrm{b}}$ & $\begin{array}{l}\mathrm{F}=23.606, \text { d.f. }=2, P \leq 0.001 \\
\text { GD-HN: } P \leq 0.001 \\
\text { GD-HF: } P \leq 0.001 \\
\text { HN-HF: } P=0.335\end{array}$ \\
\hline Decticus verrucivorus & $0.04 \pm 0.02^{\mathrm{ac}}$ & $0.21 \pm 0.05^{\mathrm{bc}}$ & $0.11 \pm 0.04^{\mathrm{c}}$ & $\begin{array}{l}\mathrm{F}=4.413, \text { d.f. }=2, P \leq 0.05 \\
\text { GD-HN: } P \leq 0.05 \\
\text { GD-HF: } P=0.227 \\
\text { HN-HF: } P=0.117\end{array}$ \\
\hline Platycleis albopunctata & $0.14 \pm 0.03^{\mathrm{a}}$ & $0.14 \pm 0.04^{\mathrm{a}}$ & $0^{\mathrm{b}}$ & $\begin{array}{l}\mathrm{F}=7.422, \text { d.f. }=2, P \leq 0.01 \\
\text { GD-HN: } P=0.908 \\
\text { GD-HF: } P \leq 0.01 \\
\text { HN-HF: } P \leq 0.01\end{array}$ \\
\hline
\end{tabular}

teran fauna of Calluna heath (e.g. as part of the Habitats Directive monitoring program).

ACKNOWLEDGEMENTS. For comments on earlier versions of the manuscript we wish to thank M. Konvička, S. Buchholz and an anonymous referee. For support during the field work we thank J. Lendzion. The study was carried out as part of the project "Biodiversity, Ecology and Management of Coastal Habitats of the Baltic Sea" and financially supported by the Bauer-Hollmann Foundation.

\section{REFERENCES}

Braschler B., Marini L., Heinrich Thommen G. \& Baur B. 2009: Effects of small-scale grassland fragmentation and frequent mowing on population density and species diversity of orthopterans: a long-term study. Ecol. Entomol. 34: 321-329.

Clausnitzer H. 1994: Zur Ökologie der Heideschrecke Gampsocleis glabra (Herbst 1786) in der Heide. Beitr. Naturk. Niedersachs. 47: 7-21.

Coray A. \& Lehmann A.W. 1998: Taxonomie der Heuschrecken Deutschlands (Orthoptera): Formale Aspekte der wissenschaftlichen Namen. Articulata 7: 63-152.

Detzel P. (ed.) 1998: Die Heuschrecken Baden-Württembergs. Eugen Ulmer, Stuttgart, 580 pp.

Dupont Y. L. \& OvergaARd Nielsen B. 2006: Species composition, feeding specificity and larval trophic level of flower visiting insects in fragmented versus continous heathlands in Denmark. Biol. Conserv. 131: 475-485.

GotTschalk E. 1997: Habitatbindung und Populationsökologie der Westlichen Beißschrecke (Platycleis albopunctata, Goeze 1778) (Orthoptera: Tettigoniidae): eine Grundlage für den Schutz der Art. Cuvillier, Göttingen, 91 pp.

INGRISCH S. 1978: Labor- und Freilanduntersuchungen zur Dauer der postembryonalen Entwicklung einiger mitteleuropäischer Laubheuschrecken (Orthoptera: Tettigoniidae) und ihre Beeinflussung durch Temperatur und Feuchte. Zool. Anz. 200: 309-320.
InGRISCH S. \& Boekholt I. 1983: Zur Wahl des Eiablageplatzes durch mitteleuropäische Saltatoria. Zool. Beitr. (NF) 28: 33-46.

INGRISCH S. \& KöHLER G. 1998: Die Heuschrecken Mitteleuropas. Westarp Wissenschaften, Magdeburg, 460 pp.

KöHLER G. \& ReINHARDT K. 2002: Zur Heuschreckenfauna der Insel Hiddensee (Mecklenburg-Vorpommern) (Insecta: Ensifera et Caelifera). Faun. Abh. Staat. Mus. Tierk. Dresden 22: 229-248.

ReINHARD H. 1962: Klimatologie. Atlas der Bezirke Rostock, Schwerin und Neubrandenburg. VEB Topographischer Dienst, Schwerin.

Riksen M., Ketner-Oostra R., van Turnhout C., Nijssen M., Goossens D., Jungerius P.D. \& SpaAn W. 2006: Will we lose the last active inland drift sands of Western Europe? The origin and development of the inland drift-sand ecotype in the Netherlands. Landsc. Ecol. 21: 431-447.

Schirmel J., Buchiolz S. \& Fartmann T. 2010: Is pitfall trapping a valuable sampling method for grassland Orthoptera? $J$. Insect Conserv. DOI: 10.1007/s10841-009-9258-6.

SChUHMACher O. \& Fartmann T. 2003: Offene Bodenstellen und eine heterogene Raumstruktur - Schlüsselrequisiten im Lebensraum des Warzenbeißers (Decticus verrucivorus). Articulata 18: 71-93.

Ssymank A., Hauke U., Rückriem C. \& Schröder E. 1998: Das europäische Schutzgebietssystem NATURA 2000 - BfNHandbuch zur Umsetzung der Fauna-Flora-Habitat-Richtlinie und der Vogelschutz-Richtlinie. Schriftenr. Landschaftspfl. Natursch. 53: 1-560.

STUKE J.H. 1995: Beitrag zur Fauna ausgewählter Insektengruppen auf nordwestdeutschen Sandheiden. Drosera 1: 53-83.

Tews J., Brose U., Grimm V., Tielbörger K., Wichmann M.C., Schwager M. \& Jeltsch F. 2004: Animal species diversity driven by habitat heterogeneity/diversity: the importance of keystone structures. J. Biogeogr. 31: 79-92. 
Tscharntke T., Steffan-Dewenter I., Kruess A. \& Thies C. 2002: Characteristics of insect populations on habitat fragments: A mini review. Ecol. Res. 17: 229-239.

Van SwaAy C.A.M. 2002: The importance of calcareous grasslands for butterflies in Europe. Biol. Conserv. 104: 315-318.

WebB N.R. 1998: The traditional management of European heathlands. J. Appl. Ecol. 35: 987-990.
Willot S.J. \& Hassall M. 1998: Life-history responses of British grasshoppers (Orthoptera: Acrididae) to temperature change. Funct. Ecol. 12: 232-241.

ZеHм A. 1997: Untersuchungen zur Nahrungswahl von Heuschrecken (Orthoptera) in zwei Sand-Pioniergesellschaften der nördlichen Oberrheinebene. Articulata 12: 131-140.

Received October 9, 2009; revised and accepted November 25, 2009 